\title{
Women Resistance on Sintren Art Performance: Analysis on Women's Argument on the Construction of Social Culture in the Coastal Community
}

\author{
Yuliawan Kasmahidayat ${ }^{1}$, Agus Nursalim ${ }^{2}$, and Tri Karyono ${ }^{3}$ \\ Faculty of Arts and Design, Indonesia University of Education
}

\begin{abstract}
This study focuses on the women's negotiation on Sintren performance which theoretically aims to elaborate the resistance and arguments of the women on hegemony found in Sintren. However, this performance can not only be done briefly, but it has to be visualized and analyzed in depth. Therefore, a descriptive analysis using Antony Gramsci's hegemony theoretical approach and literature on feminism as a formal object is applied in this study. Women's subordinate position is formed and constructed socially while a gender difference is formed by patriarchs for men's hegemony. Assumptions that resistance occurred due to injustice and gender inequality in the coastal community are shown in Sintren. This phenomenon obliged women in the coastal area to establish counter hegemony as a form of fight to reconstruct their position so gender equality can be achieved. Practically, this study is expected to increase insights on women fight for gender equality. By maximizing the self-potential and intellectual, women have the chance to dominate men, and this also can be achieved if women have a bargaining position among patriarchic domination. From this study, it can be inferred that by accentuating women's intellectual in Sintren performance collectively, women's fight against patriarchic hegemony can be acknowledged and supported, and the success on women's negotiation is also supported by women's awareness of their subordinate position in the community.
\end{abstract}

Keywords: resistance, women, performance, sintren

\section{Background}

Art can be interpreted simply as human activities in order to achieve forms of pleasure. Such forms of pleasure are satisfying when a man is capable of appreciating a relationship of elements in it (Mudjahirin, 2007: 155). Art in this sense is divided into two categories, namely the modern art (contemporary) and traditional arts. The life of traditional arts is sustained by tradition which is evolved and developed by a community or a collective people with a limited area. Therefore, artistry can be identified as a traditional art to look at the nature and characteristics of the art itself. The characteristics of folk art by Mudjahirin (2007: 156-160) can be viewed from two aspects, namely in terms of content and artistic motifs.

In terms of content, a theme or story demonstrates culture knowledge of society so that they are anonymous and belong to each other. In an art motif and each artist have their own way. Art work can be shown from memory, ability, and conformity with the spirit of the artist or the Javanese words sak kelingane (re-collection), sak isone (his best), sak kecekele (as well as he could), and sak kepenakke (and arbitrarily). Therefore, there are frequent improvisation and distortion (change each other, borrow from each other) and mutual blends of the elements in I since the folk art has many variants.

In terms of art motivation, it is generally derived from the social interests to commemorate the birth of a village, the founders of the village, and post-harvest celebrations associated with beliefs and myths of the village. The play is frequently performed and associated with mysterious exalted character of the society. Besides the folk art which also can be realized for the function of familiarity together or just fill the emptiness of the soul or relieve the boredom.

Moreover, traditional art cannot be separated from the environment to live it, the repertoire of the show is the local community and the mythology developed in the area concerned .Meanwhile, social attitudes supporters still influence the culture of the environment, to ancestral beliefs, etc. Some indications raise a variety of traditional arts, namely teledhek (is a type of traditional dance played by a young woman, usually accompanied by male dancers who changed in accordance with the musical played by a male stripper) and she got money (sawer) which can be met in some art performances such as: art lengger, ketoprak, ronggeng, and sintren. 
Based on the location of its territory, Koentjaraningrat (1994: 215-228) divides the traditional arts of Java into six (6) major groups of local arts including West coast such as Banyumas, Begelen, (Kedu), Negari Gung (Keraton Yogyakarta and Surakarta), Mancanagari (Kediri ), whereas the East coast includes Surabaya, and the land of Sabrang Wetan covers Banyuwangi. The discussion in this study was that the art of Sintren of the northern coastal areas such as Indramayu, Cirebon and Brebes which show the distinction. So, Sintren found in Banyumas has a different language used in the song. During the Sintren show, there are ten pieces of a song presented in the performances. Sometimes, it is modified with other genres requested by the watchers such as dangdut songs, pop songs coastal dependent sintren user requests based on oral literature (folk literature).

According to Danandjaja (2002: 22), called oral literature of oral folklore and still include the scope of folklore. The oral folklore consists of six categories: people's language, traditional expressions, traditional questions, poetry and folk poetry, narrative prose folk and folk songs. However, the songs in sintren were only sung during the Sintren show which lasts for part of the show. The word 'Sintren' in Javanese Baoesastra bouquet Poerwadarminta (1939) defined as, 'bangsaning soelapan, djantoeran 'something like a game meaning 'a kind of sleight of hand, the name of the show'. Making of the word 'Sintren' misleading people were to be replaced with the correct meaning. Sintren is a form of folk performing arts in the region of Central Java, Cilacap Western region and Brebes, as well as the eastern part of West Java Cirebon and Ciamis. Sintren is a folk art performance Java-Sunda; dance mystical, magical rites traditionally have certain astounding. (Herusatoto, 2008: 207) Sintren is the designation for the main character in one type of art. But eventually the title became the name of a type of art called sintren. Sintren derived word means to imitate sesantrian students play Lais, whistle, rudat or Ubrug using magic (unseen). Sintren art show is usually held at night, during the full moon in the dry season.

Ancient times when there was no electricity into the village, show this sintren using ting lamps (lanterns) and bamboo torch as a lighting tool. The performance was held on the ground who vowed mendhog (marsh grass stems), surrounded by five pieces of one and a half meter bamboo torch that is attached above the ground. But at the present time has changed, electricity had entered the village, the use of a torch is not used anymore because it has been replaced with fluorescent lamps. In the middle of the show arena installed a rooster cage made of bamboo. Location audience prepared to encircle the show arena. Torch sway in the wind, making the light in the arena stage it looks very bright, in waves, changing direction in the direction of the wind. Lanterns placed around the yard to illuminate the stands are lesehan (sitting on the mat) or on the lawn. (Herusatoto, 2008: 210). Songs dolanan Javanese children, such as Ilir-ilir, Cublak-Cublak Suweng, Padang moon, Unthuluwuk, Pring Reketek, Cing Cangkeling, Pacici-cici princess, and Slep Dur sung by a bunch of elementary school children to wait for the audience to come to the show arena,

After the time for evening prayers, chanting dolanan is replaced by a group Tanjidor folk art, as a dance sintren with Salawatan song. Tanjidor instrument consists of a drum, fly, two genjring, drum and trumpet. After Tanjidor out, a few moments later came out sintren male handler accompanied Tanjidor which immediately surrounds the amphitheater. The handler is the man pausing in the middle of the arena while picking at a chicken cage with a spell. The kemlandang (handler) that is being appealed to all the spectators who came, especially those who have high science (the science of energy in) not to disrupt the play shows that events run smoothly.

A moment later handle woman showed up with a set of clothes wore by sintren, which consists of Parang (batik cloth), a roll angkin (belt velvet embroidered) and stagen (cloth belt length of two and a half meters were rolled), black velvet blouse wore by Sintren dance embroidered decorative silver-colored and gold, shawl dance, kuluk (crown) decorated with peacock feathers, a pair of sumping (decoration earlobes dangle), ornaments of necklaces female dancers, white handkerchief, and rope yarn (mine thread) containing powder, combs, mirrors are small, and glasses black. A set of clothes are stacked neatly on the tray (tray). Then there was a small tray that contains one empty glass, a glass of water, a plate of Telon flowers (three kinds of flowers: red and white rose, ylang-ylang, and Kanthil), one bunch chew of betel, Siong cigarettes and lighters. Both trays are placed in confinement. The cell was sealed with two old color batik cloth / dark. Meanwhile, the handler of men burned incense on a fire that has been prepared on layah (plates of clay), which is twisted around over and around the chicken cage itself. Kemlandang / handler women to leave the arena and back again to accompany a young woman wearing a skirt or dress worn every day. The handler of women and young girls are sitting side by side on the east confinement, while the handler of men sitting on the west confinement. The three of them facing the cage, then the handler men asked the audience to pray together to the Lord Almighty that endowed the safety and smooth running of the operations of the performance. Kemlandang / handler of men then opened a little 
cage, then took a rope yarn female handler in it and tie it tightly to the hand of the young woman behind her. Tanjidor accompaniment stops replaced by singing songs of dolanan as early live shows.

Young women as a Sintren candidate sent into the cage that has been tilted towards the west by a handler of men, to the accompaniment of singing songs of Padang moon and Ilir-ilir. Approximately twenty minutes later, the cage was opened by the handler sintren male, then sintren came out with a makeup that is neat, pretty, wearing all the equipment shows that have been provided. In the empty glass looks saliva and the rest of chewing betel. Then sintren dancing with monotonous, funny dancing, sintren use sunglasses. The audience jostling began to pelt sintren with coins, and so the coins on his body, then sintren is going to faint.

Male Kemlandang is back reciting mantras, after some time of confinement in the open again, and sintren been dressed everyday becomes ordinary young women. Cloth, clothing, and other supplies are folded and stacked as before, though not as neat as before. Similarly sintren picture performances played by some women who incidentally coastal submissive and obedient to the kemlandang as 'controllers' performances. Obedience and subjection of the women is worthy equated with oppression and injustice of men (musicians music, handler or kemlandang, owners of capital). Usually dancers companion sintren consists of three teenage girls who were escorting sintren while being possessed by the spirit of god 'Tri Mahendra' and catch sintren that hendah fall when thrown coins by the audience.

Sintren compliance and the submission against kemlandang by Arif Antonio as hegemony, namely the power of a class against other classes underneath the persuasive ways. Hegemony is not a relationship of domination using power, but the relationship agreement with the use of political leadership and ideology (Simon, 2004: p 19). For Gramci process of hegemony occurs when the way of life, a way of thinking and the mindset of the people down, especially the proletariat has been imitating and accepted way of thinking and lifestyle of the elites who dominate and exploit them, in other words if the way of thinking of the oppressor class has been accepted and swallowed raw by the oppressed class as something ordinary, that's when the hegemony occurs in a class society (Arif, 2014: 104)

There are three levels proposed Gramci hegemony, i.e. hegemony total (integral), declining hegemony (decadent), and the hegemony of the minimum (Arif, 2014: 106). First, the integral hegemony characterized by mass affiliates approaching totality. Society shows the unity of moral and intellectual level of the firm. It appears in organizational relationship between the government and the governed. However, the relationships are not suffused with contradictions and antagonism both socially and ethically. Second, declining hegemony. In modern society, the domination of bourgeois economy is facing severe challenges, as encountered is the potential for disintegration. By the nature of this potentially meant that the disintegration was visible in the conflict that is hidden beneath the surface of social reality. That is, even if the existing system has reached or target market needs, but the mentality of the masses are not truly in tune with the dominant thought of the subject of hegemony. Therefore, the integration of social, cultural and easily collapsed. Third minimum hegemony. The third form is a form of hegemony of the lowest level. Hegemony rests on ideological unity among the elite economic, political, and intellectual coincides with an aversion to any interference of the masses in hdup state. Thus, the hegemonic groups do not want to adjust the interests and aspirations with other classes in society.

The concept of hegemony from Antonio Gramsci merely seeks to formulate new state of society is happening in all aspects of human life, especially political and social circumstances that occurred in that time era. Although the formulation can also be generalized to the socio-political situation that occurred in Indonesia. Gramci illustrates that this hegemony process occurs in every aspect of life and included in the educational aspects. The opportunity to reconstruct the position of women will occur when women have a strong bargaining position against the dominance of patriarchy. The problems are: 1) How can the bargaining position of women in the renegotiation of the patriarchal and capitalist hegemony that must be done collectively in the show sintren? 2) What are the forms of resistance and negotiation of women in the show sintren performed by consciousness that they are oppressed so that collectively they resisted the subordinate position?

\section{Literature review}

Preliminary research have been done previously, namely "Deconstruction of the Symbolic Meaning of Art Sintren (Case Study Circle Sintren Slamet Rahayu, Paduraksa Village, District of Pemalang, central Java) 
Moreover, the study entitled "Deconstruction Symbolic Meaning of Art sintren (A Case Study Circle Sintren Slamet Rahayu Village Paduraksa, District Pemalang), with the aim to perform on Art Sintren reinterpretation in the present context. The research method in the realm of science Cultural Studies using qualitative data analysis methods and techniques of data analysis using descriptive and interpretative approaches and theory of Deconstruction Derrida. In this study show the symbolic meaning of Art sintren material is the object of a study on the deconstruction of the symbolic meaning. There are three findings in this study. First, the deconstruction of the symbolic meaning of Art sintren is caused by the death of metaphysics driven two aspects: first, (1) the opinions and people's appreciation of the arts sintren; and (2) Art sintren in the midst of modern art. Second, the process that occurs in the deconstruction of the symbolic meaning sintren art can be understood through two processes, namely: (1) from the romance and lifestyle into a folk art; and (2) sintren of folk art into modern art. Third, the deconstruction of the symbolic meaning of Art sintren has implications for the socio-economic and cultural life of Pemalang society.

Unless it also has conducted a study on Sintren from a different angle, namely: Study Meaning, Cultural Values, and Context Traditional Art of Indramayu Sintren well as the efforts of inheritance, the results of the study have been summarized as follows: Assessing the changing patterns show sintren adapted to modern developments, Modernization has opened wide access to the diffusion between the indigenous culture (core) with a new culture came (secondary). Sintren, as a folk art, also changed to maintain its existence in the world competition in popular entertainment. However, the characteristic simplicity of folk performing arts until now remained prominent. If there is a sophistication which is not found in the telefilm, but only the outward image alone. Similarly, the performances sintren, the changes do not occur in ritual and mystical, in this case the ritual incense, confinement, Balongan, possessed by spirits. Changes occur in the clothing, songs, musical instruments, and the place was used. Clothing is used, if the first is a kebaya (traditional clothes of women antiquity), then now is the fashion doll clothing (shirt without sleeves are typically used by dancers puppet).

Songs were sung and musical instruments is also changed. To attract the audience, the songs sung at the beginning of the show which often uses dangdut songs and campursari at the time. But when sintren will start to dress up and the show will begin, the song "turun sintren" becomes anthem. The song was intended to invite the spirits that will permeate the body of the dancer. Musical instruments and equipment sound system has also been using modern tools as enliven, such as the use of guitar, flute, drums, and microphone usage by sinden.

The place used today, unlike earlier times in the open, on the ground marsh grass stems, surrounded by five pieces of bamboo torch high as one and a half meter is plugged in on the ground as illumination. In the middle of the performance installed a large cage made of bamboo covered with cloth. After modernization, the venue was filled with lights ablaze, in the middle of the show arena remains mounted large cage covered with colorful fabric.

Through these changes, the sintren performance currently living in the community is not mystical (wingit) again (the term of the Java language to call "mystical"), but simply to entertain people as container maintain traditional culture and art. Moreover, the existence of traditional art performances will not only release the existence of art, because usually during the show will always be accompanied by folk market presence that provides a variety of food and traditional items. Food and goods are today is not easy to find.

\section{Discussion}

The object of study is the resistance and negotiation of women in the Performing Sintren. Research resistance and negotiation of women using Gramsci's theory of hegemony and feminist literary criticism as a formal object. The position of women is subordinated shaped and constructed both socially and culturally. Their sex and gender differences are deliberately shaped by patriarchal and capitalist hegemony for the life of men. Female resistance occurs because of the injustice and gender inequality in the society. This phenomenon causes women to counter the hegemony as a form of struggle to reconstruct the position of women so as to achieve gender equity. Theoretically, this research aims to uncover resistance and negotiation of women against patriarchal hegemony in the show Sintren. In practical terms this study can contribute how women struggle to successfully achieve gender equality as desired by feminists.

Feminism is a movement of revolt against the men, the struggle against the existing social institutions, such as domestic institutions, marriage, and women's efforts to deny the nature of the rebellion. Because of their prejudice, then feminism has no place in women, even rejected by society, while according to feminists, 
feminism, like the case of his school of thought and movement of others, is not a thought and movement that stands alone, but it covers a wide range of ideologies, paradigms and theories he uses.

The goal of feminism that is a concern to fight for the fate of women (female players) in the show of Sintren. It is (as perceived by author) because there is his awareness that women were oppressed, exploited, and trying to avoid the oppression and exploitation. For feminists, the emergence of this understanding is a major step in their mission to give freedom to women. Issues of gender equality is not the only thing that is required in the feminist movement. Several other issues are also discussed in the other's perspective, such as: group, power, identity, community, institutions, governance structure, imbalance, justice, conflict, violence, peace, and security.

P3S feminist group (the Women Player Sintren) think that the player indicator is not only based on the major players and assistant player, but also pay attention to the overall player in the decision-making performances. Power here is a tool to force someone to do something they would not do as an option. Power possessed by a person is affected by its autonomy on the power of others. Ann Tickner found Power concept expressed by Morgenthau is androcentric, that is only focused on the development of self-concept and objectivity men where men are regarded as the owner of the position over women. While in terms of peace, there is a debate between the three main approaches to feminism, namely: liberal feminism, socialist feminism and radical feminism. Liberal feminism is more focused on the discussion about the equality between men and women. Mary Wollstonecraft in his book entitled "A Vindication of the Rights of Women" in 1792 stated that women should have the same access as men to the economic and educational fields. In this perspective, feminists wanted the contribution of women in politics more calculated.

Socialist feminism is heavily influenced by the theory of Marxism. Here there is a presumption that equality between men and women have been lost because of the freedom of women has been widely taken over by the patriate community. In this case, Rosemarie Putnam Tong found male control over women should be abolished. Meanwhile, in the perspective of radical feminism, women's freedom can only be achieved through a transformation in human relations in the sphere of the most personal and intimate relationship. In addition, radical feminism also developed the concept of patriarchy to describe the act of male domination over women, and specifies that gender is not just a question of identity or sexuality.

Feminists highlights women as a group and gender identity as a unit of analysis in world politics and how the achievement of sovereignty over women as men attainment of sovereignty issues. Feminism group considers gender as a variable in the policy-making process by exposing the domination of the men and their masculine characteristics as the main character who make the decisions in the process of achieving the interests of the group. Rebecca Grant and Kathleen Newland argues that this study only focuses on conflict and anarchic conditions and set out to find the appropriate strategy and focused on competition and fear. Positivist thought that theory and analysis can only be legitimized if the research is conducted in accordance with the principles and methods that have long existed. While post-positivism assume that the knowledge received in the field is usually tinged with a consensual understanding on a discipline that has been accepted by experts. Further exploration of the feminism says that gender is one of the constitutive dimensions of political identity because politics has become associated exclusively as an activity which is mostly done by men as well as separate from femininity and female activity.

In the end, the women began to be considered as a significant actor in the movement of social criticism, organizing peace, environmental law, and the liberation of women is transnational. This makes the life of a woman seen in a gender-sensitive research has policy relevance and effect materialist. Proponents of feminism assumed that as women are known as the fundamental aspects in the processes of political and economic, they would be considered equivalent in social policy making.

The conclusion to be drawn from the review above is that there are three feminists' challenges are discussed in this chapter, namely: the debate different gender issues, transformation of constitutive theoretical and epistemic categories in science international relations. Feminists consistently gives attention to the insecurity that accompanies the process of massive change and transition deconstruction world. Even though, feminists do not consider women as "victims" of feminism also deals with ways both in the accession process to change their position in the social an environmental favorable characteristic. Although the new feminism influence in the study of International Relations in the 1980s, experts thought that the concept has been around a long time. Feminists also has demonstrated its ability to contribute in many important aspects of international relations. There are many assumptions that men cannot enter into feminists. Many feminists who consider men and 
students as "good feminists" when they engage the ideas of feminism and incorporate concepts and analysis of feminism within their purview.

Although the opinion is pluralistic feminist, but one thing that unites them is their belief that society and legal order is patriarchal. The rule of law is said to be neutral and objective often just a cover against political and social considerations driven by the ideology of the decision maker, and ideology is not for the benefit of women. The patriarchal nature of society and the law is the cause of injustice, domination and subordination of women, and consequently claims against gender equality. Gender equality cannot be achieved in the institutional structure of the ideological currently in force. Focusing on a feminist analysis of the role of the law against the persistence of patriarchal hegemony. All the analysis and the theory advanced by feminists then expected to be significantly enforced, because any attempt feminists not only to adorn the pages of history of human development, but rather the human effort to survive. The emergence of the feminist movement is the description that the provisions of the abstract (not clear) is unable to complete inequality.

Social changes in women can be seen after a movement of thought and feminism. Before their thoughts and movements, the situation of women is very alarming. It can be seen from the injustice to acquire the rights to life, such as economics, politics, education and employment. In addition, the role of social inequality in the lives of women and men. And many women violence is accepted at the time. This led to the idea to fight for the lives of women for the better players. As in Indonesia in general appear a thought that the same movements like feminism have the same goal which is to fight for the rights of women who pioneered by RA Kartini whose effects can be felt to this day. Where women are considered equal to men. With the existence of a thought and the feminist movement have significant impacts. Seen in life today. For example, many women have gained equal work with men and could even be higher. The women are also capable of being a leader.

\section{Finding}

Feminism is understood that drive the understanding and awareness about the lives of women, especially women's life experiences injured. Furthermore feminism is a movement that is based on their awareness of the oppression of women which was followed up by their actions to resolve the persecution.

The definition of feminism fight for equal rights but the sex is different. The purpose of this ideology or movement is to exempt any private women through the mobilization of solidarity among the women. This means that invites women to realize that each individual woman is different. Both men and women are different for each person. Stereotypical view individual causes loss of consciousness and identity. Both men and women have similarities and differences in nature and by culture (nurture). That feminism contains three essential components: First, a belief that there is no difference in rights based on sex (sex equality), which is opposed to their position in the hierarchy between the sexes. The equation is not only quantity, but the quality as well. The position of hierarchical relationships produces superior and inferior position. Here happening control from superior to inferior group. Secondly, a recognition that in a society there has been a social construction that brings disadvantages for women. The relationship between men and women that have now is the result of a social construction, not determined by nurture (the divine nature), Third, In connection with the second component, namely the existence of gender role identity. Feminism used differences which are mixed by sex and gender, so that women used separate group in society. As a result of this grouping, women became "the other human being" and not human (human norm), as a result of this social grouping, women are difficult to be aware of personal existence (identity). Women in sintren performances of the view that the cause of the oppression of women is capitalism there also were found to agree with radical that patriarchy is the source of oppression. Feminism has become an international movement. Gender equality is not just a movement in Indonesia, a country with a strong patriarchal culture, but also a world movement. Movement for gender equality will always be there as long as the culture of patriarchy still shackle women of the freedom of work and aspire.

\section{Conclusion}

In one group of Sintren performance, each Sintren brought two female crew; one sintren player, four women as her ladies and one person as kemlandang and two women as singers in the show, two stylists for actors and actresses. The results showed an average crew of women in the group of sintren performance are only primary 
school graduates or even they did not go to school at all. The performers in the show of sintren recruited women of fisherman's children from coastal area.

The results of this study can be concluded that the subordinated position of women is the result of the construction of the patriarchal and capitalist both socially and culturally. Subordinated position of women has a chance to dominate the men when women are able to utilize the potential and intelligence. Opportunities for women to reconstruct the position of women will occur when women have a strong bargaining position against the dominance of patriarchy. Bargaining position of women will bring renegotiation of patriarchy. Women struggle to get out of the patriarchal and capitalist hegemony must be done collectively. In addition, the success of women's resistance and negotiations should be supported also by the awareness of women that they are oppressed so that collectively they resisted the subordinate position. Feminism has become an international issue. Gender equality is not just a movement found in Indonesia, a country with a strong patriarchal culture, but also a world movement. Movement for gender equality will always be there as long as the culture of patriarchy still shackle women of the freedom of work and aspire.

\section{Acknowledgement}

I would like to thank to: The Minister of Research and Technology of Higher Education. The Rector of Indonesia University of Education Bandung, West Java, and Mohammad Arifin II (The Prince of Kasepuhan Palace, Cirebon, West Java) for their contribution to run the research very well.

\section{Bibliography}

[1] (n.d.). Retrieved from sandiwaradanperang.blogspot.com: http://sandiwaradanperang.blogspot.com/2009_10_20_archive.html

[2] (2009). Retrieved December 28, 2009, from pikiran-rakyat.com: http://iklan.pikiran-rakyat.com

[3] Arif, S. (2001). Pemikiran-pemikiran Revolusioner. Yogyakarta: Pustaka Pelajar.

[4] Bruno, N. (1983). The Study of Ethnomusicology: Twenty-Nine Issues and Concept. Urbana: University of Illinois Press.

[5] Budiono, H. (2008). Banyumas: Sejarah, Budaya, Bahasa dan Watak . Yogyakarta: LKis Pelangi Aksara Yogyakarta.

[6] Christomy, Tomy, \& Yuwono, U. (2004). Semiotika Budaya. Jakarta: Pusat Penelitian Kemasyarakatan dan Budaya Direktorat Riset dan Pengabdian Masyarakat Universitas Indonesia.

[7] Daeng, J. H. (2000). Manusia, Kebudayaan, dan Lingkungan. Jakarta: Pustaka Pelajar.

[8] Danandjaja, J. (2002). Folklor Indonesia: Ilmu Gosip, Dongeng, dan lain-lain. Jakarta: Pustaka Utama.

[9] Fandy, H. (2009). Sintren: Kesenian Magis yang Menyejarah. Bandung.

[10] Faqih, M. (2001). Pendidikan Popular Membangun Kesadaran Kritis. Yogyakarta.

[11] Herusatoto, B. (2008). Banyumas: Sejarah, Budaya, Bahasa, dan Watak. Yogyakarta: LKis.

[12] Hood, B. (2014). Semiotik dan Dimensi Sosial Budaya. Depok: Komunitas Bambu.

[13] Ismail, M. G. (1991). Seuneubok Lad, Uleebalang dan Kumpeni. Perkembangan Sosial Ekonomi di Daerah Batas Aceh Timur 1840-1942. Belanda: Universitas Leiden.

[14]Johnson, D. P. (1990). Teori Sosiologi: Klasik dan Moderen, Jilid III, Terjemahan oleh Lawang, Robert, M.Z. Jakarta: Gramedia Pustaka Utama .

[15] Jurgen, H. (1984). Theory of Communication. Boston, USA: Beacon Press.

[16] Kasmahidayat, Y. (2010). Transformasi Budaya Nusantara . Bandung: PT. Bintang Warli Artika.

[17] Koentjoroningrat . (1987). Sejarah Teori Antropologi . Jakarta: UI-Press.

[18] Kuntjaraningrat. (1994). Kebudayaan Jawa. Jakarta: Balai Pustaka.

[19] Mark, D. (1995). Sejarah Musik Liturgi. Yogyakarta: Pusat Musik Liturgi.

[20] Mudjahirin, T. (2007). Memahami Kebudayaan. Semarang: Fasindo .

[21]Pelly , U., \& Menanti , A. (1994). Teori-teori Sosial Budaya . Jakarta : Direktorat Jenderal Pendidikan Tinggi Departemen Pendidikan dan Kebudayaan. 
[22] Poerwanto, H. (2000). Kebudayaan dan Lingkungan dalam Perspektif Antropologi . Yogyakarta: Pustaka Pelajar.

[23] Pradopo, R. D. (2005). Pengkajian Puisi Yogyakarta . Yogyakarta : Gajah Mada University Press.

[24] Purwadi , d. (2005). Ensiklopedi Kebudayaan Jawa . Yogyakarta : Bina Media .

[25] Rizer, G. (1996). Sociological Theory . New York: The MacGraw Hill Companies.

[26] Santoso , L. (2010). Episitimologi Kiri . Yogyakarta : Aruzz Media .

[27] Sharpe, R. (2000). Music and Humanisme: An Esay in the Aesthetic of Music. New York: Oxford University Press.

[28] Simon, R. (2004). Gramci Polictical Thought . Yogyakarta : Pustaka Pelajar.

[29] Soekatno. (2003). Seni Pertunjukkan Wayang Ruwatan: Kajian Fungsi dan Makna Harmonia. Harmonia, IV No.1/ Januari-April.

[30] Steans, Jill, Llyod, \& Thomas, D. (2005). Introduction to International Relations, Perspectives \& Themes. UK: Pearson \& Longman.

[31] Sudarsono, R. (1985). Keadaan dan Perkembangan Bahasa, Sastra, Etika, Tatakrama, dan Seni Pertunjukkan Jawa, Bali, dan Sunda. Yogyakarta: Proyek Javanologi.

[32] Surjo, D., Soedarsono, R., \& Soekiman, D. (1985). Gaya Hidup Masyarakat Jawa di Pedesaan: Pola Kehidupan Sosial-Ekonomi dan Budaya. Yogyakarta: Proyek Penelitian dan Pengkajian Kebudayaan Jawa, Departemen Pendidikan dan Kebudayaan.

[33] Susanto, B. (2009). Penghibur(an): Masa Lalu dan Budaya Hidup Masa Kini Indonesia . Yogyakarta : Kanisius.

[34] Tegar, F. (2009). Retrieved December 29, 2009, from suaramerdeka.com.

[35] True, J. (2001). Feminism, in: Scott Burchill, et al, Theories of International Relation. Palgrave.

[36] Weber, M. (1961). Social Action and Its Types. New York: The Free Press. 